\title{
DETERMINANTES DO COMPORTAMENTO DE COMPRA DOS PRODUTORES DE GRÃOS: UM ESTUDO MULTICASOS COM MÉDIOS E GRANDES PRODUTORES DO ESTADO DO MATO GROSSO
}

\author{
SCARE, Roberto Fava. Prof. Dr. do Departamento de Administração da Faculdade de Economia, \\ Administração e Contabilidade de Ribeirão Preto. FEA-RP/USP. Coordenador do AgroFEA - Programa de \\ Agronegócios da FEA-RP/USP. Email: rfava@usp.br \\ ANTOLINI, Leonardo Silva. Graduado em Administração de Empresas pela FEA-RP/USP e Pesquisador \\ do AgroFEA. Email: 1santolini@ fearp.usp.br
}

\section{RESUMO}

Nos últimos anos, o agronegócio brasileiro tornou-se importante demandante de insumos, bens de capital, serviços financeiros e tecnologia. Além disso, há alterações no tamanho das propriedades, gestão do risco e comercialização, educação e atitude dos responsáveis pela tomada de decisão dos empreendimentos agropecuários. Nesse ambiente de mudança, o entendimento de certas variáveis é relevante para a estratégia de marketing das empresas fornecedoras de insumos, pois elas influenciam no modelo de negócio e comportamento de compra dos produtores rurais. O propósito desse trabalho é desenvolver entendimento e familiaridade acerca do comportamento de compra dos produtores de grãos do Estado do Mato Grosso, no intuito de compreender a influência das características do produtor e da fazenda, gestão do negócio e do risco, tomada de decisão, fontes de informações, produtos e fornecedores. Para tanto, realizou-se um estudo multicasos com três produtores de grãos do Estado do Mato Grosso, por meio de entrevistas presenciais. Verifica-se que os determinantes mais influentes no comportamento de compra dos produtores estudados são o nível de envolvimento na tomada de decisões, benefício esperado por tipo de produto, tamanho da atividade, culturas produzidas, rotação de culturas e sua relação com produtividade. Além destes fatores, a propriedade da terra, rentabilidade do negócio, restrições de crédito e gestão de risco influenciam no nível de capitalização e na escolha das ferramentas de aquisição de insumos e bens de capitais. Por fim, mas não menos importante, as fontes de informação e sua qualidade impactam na lealdade do produtor à marca, ao distribuidor locale ao vendedor.

Palavras-chave: Marketing; Comportamento de compra; Produtor rural; Estudo multicasos.

Determinants of Buying Behavior of Grain Producers: A Multiple Case Study with Mid and Large Size Producers in The State of Mato Grosso

\begin{abstract}
In recent years, Brazilian agribusiness has demanded for inputs, capital goods, financial services and technology. In addition, there have been changes in the size of the properties, as well as in risk management and commercialization practices, and level of education and posture of those responsible for the decision making of agricultural enterprises. It is fundamental for companies that supply inputs and services to farmersto understand some variables in such changing environment, considering that they influence the business model and the buying behavior of rural producers. The purpose of this study is to develop knowledge and familiarity with the buying behavior of grain farmers in the State of Mato Grosso, with the intent of understanding how this behavior can be influenced by theproducer's profile and the farm features, as well as the risk and business management practices, the decision making, the sources of information, and the products and suppliers. In order to achievesuch a goal,
\end{abstract}


a multiple case study was developed by interviewing, face to face, three grain producers, from the State of Mato Grosso. The results demonstrate that the most influential determinants on the buying behavior of the interviewed producers were their level of involvement in the decision making process, the benefit they expect from each type of product, the size of their farming operation, the kind of yield production, and the crop rotation and its relation to productivity. Additionally, the ownership or not of the land, the business profitability, credit restrictions and risk management, they all influence the level of the producer's capitalization and consequently his choices of channels for acquiring inputs and capital goods. Last, though not less important, the sources of information and their reliability have an impact on the producer's loyalty to a brand, or to a local distributor or to a salesperson.

KEYWORDS: Marketing; Buying behavior; Farmers; Multicase study.

\section{INTRODUCTION}

Brazil is one of the world's largest producers and exporters of agricultural commodities and in recent years only a few countries have grown in global agribusiness as expressively as Brazil did. Currently, the country is one of the largest producers of food, along with the United States, Argentina and East Europe. Brazil is the largest producer and exporter of coffee, sugar, ethanol and fruit juices. It also ranks first among sales leaders of soybean, beef, chicken, tobacco, leather and leather footwear. Projections indicate that the country will soon become the main hub for production of cotton, sugar cane biofuels and vegetable oils (MAPA, 2010).

Such growth has been followed by many changes in the market. Lately, the Brazilian agricultural sector has rapidly become a strong consumer of inputs, capital goods, financial services and technology. The significant incorporation of new advancements such as the use of transgenic seeds, precision agriculture, increased use of fertilizers and crop protection has been a remarkable changing factor, as well as the increasing globalization, the pressure on cost and prices, and on the rational utilization of resources, the consolidation of suppliers and the arrival of new entrants. All aforementioned subjects have introduced important changes in the business environment. Additionally, there have been changes in the farm structure, such as size, risk management and commercialization, education and behavior of those responsible for the decision making process (SCHNEPF, DOHLMAN and BOLLING, 2001).

These elements affect the business model and the producer's buying behavior, and may have an influence on how suppliers market their products and services to producers. It is imperative for such companies to understand the relation of external factors, the farm business model and their impact on the buying behavior of farmers in order to be successful when developing relationship marketing strategies.

Farm input providers can play a highly influential role not only in supplying the materials needed to produce feed, food and biomass, but also in providing the financial services and scientific expertise so farmers can manage the production process more effectively and efficiently (BURGERT, 2011).

All these factors have collaborated for the need to better understand farmers' buying behavior in Brazil and the relation of their behavior with the changing business environment. However, although private organizations often conduct studies on buying behavior of Brazilian farmers, as the BrazilianAssociation of Rural Marketing and Agribusiness (ABMR\&A; www.abmra.org.br) and the Kleffmann Group (www.kleffmann.com/opencms/opencms/pt/), only a few academic studies can be found about this subject. (ROSSI, NEVES and TORNAVOI, 2003; HABERLI JR, 2006; SILVA, SCARE and CASANOVA, 2008; SCARE et al., 2011; SCARE, ANTOLINI and MIRANDOLA, 2012). International studies can be found specifically in the U.S, Argentina, the Netherlands and Canada (FUNK and TARTE 1978; KOOL, 1994; GLOY and AKRIDGE, 1999; ALEXANDER et al., 2008; FEENEY et al., 2010).

Based on literature review, six main elements 
affecting buying behavior of farmers can be cited: Producer and Farm Characteristics, Risk and Business Management, Decision Making and Information Sources, Products, Suppliers and External Environment.

And even though these researches are mainly quantitative, they have provided solid elements that were operationalized in our case study protocol. Likewise, both the collaboration with The Center for Food and Agricultural Business at Purdue University and with the Center for Food and Agricultural Business at Universidad Austral has been fundamental for the development of this qualitative research in Brazil.

The outcome of this qualitative study will contribute to further knowledge about the buying behavior of Brazilian farmers, , which from one perspective may help input supply companies to delineate more precise marketing programs aimed at producers while being an initial step for future quantitative studies over this topic in Brazil.

\section{ОвJectives}

The objective of this paper is to develop familiarity with the nature of the farming business model and its influence on buying behavior of grain producers in the State of Mato Grosso-Brazil, as well as develop guidelines for future studies, using the multiple case study method.

The specific objectives are to portray the studied producers and their farms, their business and risk management practices, their process for decision making and information sourcing and the relation of such aspects with the buying process of inputs, capital goods and financial services. We also aimed to generate insights about Brazilian producers' buying behavior and how it relates to brand, price, local suppliers and the salesperson, by describing three case studies.

\section{Theoretical BaCkground}

Considering the objective of increasing familiarity with the nature of the farming business model and its influence on the buying behavior of grain producers in the State of Mato Grosso, previous studies have been reviewed with the intent of organizing the main preceding aspects namely: 1) Producer's Characteristics; 2) Farm Characteristics; 3) Risk and Business Management; 4) Decision Making and Sources of Information and its influence on the decision making; 5) Products and Suppliers chosen.

The first two factors preceding the purchase decision are the Producer and the Farm characteristics. Producer Characterization includes: Main activities on farm, Decision making level, Age, Gender, Lifetime in agricultural activity, Education level, Importance of agriculture in the producer's income, Place of residence and Distance from Farm. For Farm Characterization, the factors considered were: 2011 Gross sales, Production area, Land structure, Main cultures, Productivity, Level of technology, Irrigation systems, Direct planting, Use of Transgenic Seeds, Crop Rotation and Crop Succession.

Aspects related to Risk and Business Management and the Decision Making Process were discussed so as to analyze the farming business model. To begin with, the Risk and Business Management factor was analyzed based upon Production financing, Equipment Financing, Credit Restrictions, Production commercialization, Storage systems, Participation as a member of an association and/or a cooperative, Influence of productivity yield on business management, and Farming operation changes over next five years. Secondly, the Decision Making and Sources of Information aspects include variables as: Sources of advertising, Reliability of media, Sources of technical information, Reliability of sources of technical information, Buying process complexity, Technical information gaps between different local sources, Trust on local suppliers, and Influence of local suppliers on buying decision.

Finally, the influence of previous aspects determines the farmer's decision about products and input suppliers. Regarding these aspects, Product and Suppliers choices entailed the following variables: Benefits expected from inputs, Benefits expected from equipment, Benefits expected from financial services, Differences between brands of inputs, equipment and 
financial services, Price differences between inputs, equipment and financial services, Loyalty to local suppliers and Loyalty to salesperson. (ROSSI, NEVES and TORNAVOI, 2003; HABERLI JR, 2006; SILVA, SCARE and CASANOVA, 2008; SCARE et al., 2011; SCARE, ANTOLINI and MIRANDOLA, 2012; FUNK and TARTE 1978; KOOL, 1994; GLOY and AKRIDGE, 1999; ALEXANDER et al., 2008; and FEENEY et al., 2010).

\section{Procedures}

We have conducted a field study with multiple case studies. We have studied 3 Large Commercial grain Producers from the three main production regions of Mato Grosso: Chapada dos Parecis, BR-163 and Araguaia Valley, respectively, from the cities of Diamantino, Lucas do Rio Verde and Querência. Figure 1 shows the location of the three cities in the State of Mato Grosso. The darker areas represent the three cities territory.

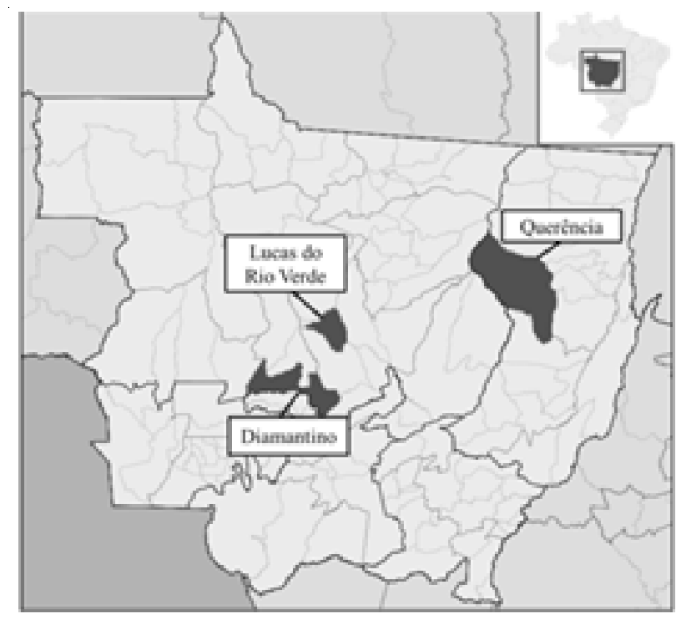

Figure 1 - Location of Diamantino, Lucas do Rio Verde and Querência. State of Mato Grosso, Brazil. Fonte: pt.wikipedia.org

The case study protocol was built based on our literature review and it considered: 1) Producer's Characteristics, 2) Farm Characteristics, 3) Risk and Business Management, 4) Decision Making and Sources of Information and 5) Products and Suppliers.

Based on Yin (2005), the multiple case study method was chosen in order to investigate the farmer's buying process in its real context, requiring the use and analysis of various sources of evidence: semi-structured interviews, files, documents, and observation. Following the Merriam (1988) case study classification, the 03 case studies proposed were considered descriptive case studies for reporting in detail the social experience that involves configuration, structures, activities, and changes in time and relationship with other experiences.
The 03 case studies are considered embedded on grain farmers buying process in Mato Grosso State.

As a compliance of the research protocol, direct observation and face-to-face semi-structured interviews have been conducted with farmers who are owners and key decision makers. On average, each interview lasted 1 hour and 30 minutes and they were performed in September 2012, in locus. All information is based on 2011 and 2012 soybean crop period.

\section{Results}

The results presented below follow the logic proposed by Yin (2005). Therefore, the starting point is to describe and analyze individual reports on each case. Next, to perform a joint analysis of the 03 cases 
to consolidate the information found in the field and to compare them with the theory discussed in the literature review as a conclusion. To present the results in a simple way we used the same structure of ourcase study protocol. The names of the interviewed producers were not stated, and we used the name of the cities where their farms are located in order to identify themin this work.

\section{Producer from Diamantino \\ Producer and Farm Characteristics}

This producer is a 50-year-old man, graduated in agronomy and the only responsible for planning and management activities, purchase of inputs and sale of production, being the primary decision maker of the farm. He lives in the city of Cuiabá, the capital of Mato Grosso, located 188 kilometers (116 miles) away from his farm. He has been farming for 17 years and agriculture represents $100 \%$ of his earnings. The production of his farm is based on soybean and sorghum, occupying an area of 3,700 hectares. In 2011, gross sales of his farm were between US\$2,000,000 and US\$3,000,000, which classify him as a large commercial producer, specifically in the State of Mato Grosso. This producer shows low levels of productivity $(2,820 \mathrm{~kg} / \mathrm{ha}$ for soybeans and $1,500 \mathrm{~kg} /$ ha for sorghum), low use of technology and the land is $100 \%$ rented.

This production structure creates limitations for the purchase of inputs that can increase his productivity and sustainability in the long term, due to the existing risk of breaking the land contract which in turn makes his investments nontransferable to other lands. He prefers not to invest in land productivity, competing at a low cost strategy. For example, the productivity of sorghum, described by him as low yield, occurs due to the use of only a few types of inputs (herbicides and seeds) which reduces production costs in one side, but also reduces productivity on the other. These factors make the production profitable in the short term, but they are detrimental in the long term.

\section{Risk and Business Management}

Another factor that affects the buying behavior of this producer is crop succession and crop rotation. In
2010, he attempted to plant corn in the second crop but he failed due to the fact that the planting window was not favorable at that time. This made him consider the second crop as being too risky due to corn price variations in that period. In other words, he did not buy inputs for corn production. Besides, not performing crop rotation is risky to business and land sustainability. This situation can also be explained by land leasing and the risk of non-renewal of the contracted area.

This producer promotes barter operations with local suppliers to finance production, exchanging part of the production for inputs before harvest. He also does forward contracts. These operations reduce the risk of future price variations. When buying equipment and machineries, he uses government funding and private banks.

It was recognized by this producer that the barter operation makes him more loyal to the local supplier, reducing his information search for inputs, and negatively affecting his profitability and investment levels. It is noteworthy that the barter operation is held by this producer as a result of his credit restrictions from banks and other financial agents, making barter operations one of the few sources for his production financing. This producer takes part of an association and a cooperative. These memberships are important for him as these institutions provide improvements in producers and workers' capabilities, they represent the grain producers politically and they are sources of technical information. The cooperative organizes a buying pool of farmers and this group of producers also affects the buying behavior of each other.

\section{Decision Making and Sources of Information}

This producer is exposed to advertisements from television and Internet. He partially believes in such information and he also searches the veracity of this information at the local supplier, by participating in field days and by interacting with other producers and technical organizations. He also believes that buying inputs is becoming more complex, because there are more options for purchasing inputs, more sales channels (retail, trading, cooperative, direct selling) and products 
with similar functions.

This producer believes that there are differences between information from different local suppliers and he partially relies on such information. Usually, when buying inputs, he is influenced by technical representatives from a few local suppliers.

\section{Products and Suppliers Chosen}

This producer's main expected benefits when purchasing inputs are quality with competitive prices and product line extension. These attributes are associated to a few brand companies, exerting a degree of influence on buying behavior. For him, there are only brand differences in seeds, chemicals and equipment. Fertilizers and financial services brands are considered as relatively the same. In terms of pricing, he believes that there are price differences between brands of seeds, chemicals and equipment. He does not consider himself as being loyal to any local supplier, although he buys from only a few of them.

The producer only buys products with proven performance by field day, by confirmed information and by hearing from other producers. Regarding equipment, an extensive dealer network and availability of replacement parts are considered more important than price and brand. For financial services acquired, the producer considers agility, price and amount as factors influencing his decision. Although the producer believes that the local distributors and salesperson influence his decision, he is not loyal to them. Exhibit 1 shows the results of the interview with the producer from Diamantino, Mato Grosso State, Brazil. 
Exhibit 1 - Consolidated results of the interview with the producer from Diamantino. State of Mato Grosso, Brazil.

\begin{tabular}{|c|c|c|}
\hline Diamantino & Analytical column & Results \\
\hline \multirow{9}{*}{$\begin{array}{l}\text { Producer } \\
\text { Characteristics }\end{array}$} & Main activities on the farm & $\begin{array}{l}\text { Planning and management activities, } \\
\text { purchase of inputs and sales of production. }\end{array}$ \\
\hline & Level Decision Making & Only decision maker \\
\hline & Age & 50 years old \\
\hline & Gender & Male \\
\hline & Time in agriculture activity & 17 years \\
\hline & Education & Agronomic Engineer \\
\hline & Importance of agriculture in producer's income & $100 \%$ \\
\hline & Lives in the city? & Yes, Cuiabá - MT \\
\hline & Distance to the farm & $180 \mathrm{~km}(116$ miles $)$ \\
\hline \multirow{10}{*}{$\begin{array}{l}\text { Farm } \\
\text { Characteristics }\end{array}$} & 2011 Gross Sales & between US\$2,000,000 and US\$3,000,000 \\
\hline & Production Area & 3.700 hectares \\
\hline & Land structure & $100 \%$ of rented lands. \\
\hline & Main Cultures & soybeans and sorghum \\
\hline & Productivity & $\begin{array}{l}2.820 \mathrm{~kg} / \mathrm{ha} \text { soybeans and } 1.500 \mathrm{~kg} / \mathrm{ha} \\
\text { sorghum }\end{array}$ \\
\hline & Level of technology & low \\
\hline & Irrigation & no \\
\hline & Direct planting & yes \\
\hline & Use of transgenic seeds & no \\
\hline & Crop Rotation and Crop Succession & not frequently \\
\hline \multirow{9}{*}{$\begin{array}{l}\text { Risk and } \\
\text { Business } \\
\text { Management }\end{array}$} & Production Financing & Barter operation \\
\hline & Equipment Financing & Government funding and private banks. \\
\hline & Credit Restrictions & yes \\
\hline & Production Commercialization & Barter operation and forward contracts \\
\hline & Storage Systems & no \\
\hline & Member of an Association and/or Cooperative & yes \\
\hline & What is the Influence of productivity on business management? & $\begin{array}{l}\text { "The productivity is linked to income and } \\
\text { investment in the farm" }\end{array}$ \\
\hline & How may your farming operation change over the next five years? & $\begin{array}{l}\text { "Will increase, investing in machines and } \\
\text { human capital" }\end{array}$ \\
\hline & Sources of advertising / media & Television and Internet \\
\hline \multirow{7}{*}{$\begin{array}{l}\text { Decision } \\
\text { Making and } \\
\text { Sources of } \\
\text { Information }\end{array}$} & Do you trust the information provided by the media? & partially \\
\hline & Sources of technical information & $\begin{array}{l}\text { local supplier, field days, interaction with } \\
\text { other producers and technical organizations. }\end{array}$ \\
\hline & $\begin{array}{l}\text { Do you trust the information provided by sources of technical } \\
\text { information? }\end{array}$ & 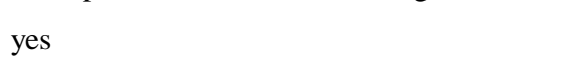 \\
\hline & For you, is buying inputs becoming more complex? & yes \\
\hline & $\begin{array}{l}\text { Are there differences between information from different local } \\
\text { suppliers? }\end{array}$ & yes \\
\hline & Do you trust the information provided by your local supplier? & yes \\
\hline & Regarding local suppliers, what influences your buying decision? & $\begin{array}{l}\text { Technical representatives from a few local } \\
\text { suppliers. }\end{array}$ \\
\hline \multirow{11}{*}{$\begin{array}{l}\text { Products and } \\
\text { Suppliers }\end{array}$} & Inputs Expected benefits & $\begin{array}{l}\text { quality with competitive price and product } \\
\text { line extension }\end{array}$ \\
\hline & Equipment Expected benefits & Reposition parts and network \\
\hline & Financial Services Expected benefits & \\
\hline & Are there differences between brands of inputs? & yes \\
\hline & Are there differences between brands of equipment? & yes \\
\hline & Are there differences between brands of financial services? & no \\
\hline & Are there differences between prices of different brands of inputs? & yes \\
\hline & Are there differences between prices of different brands of equipment? & yes \\
\hline & $\begin{array}{l}\text { Are there differences between prices of different brands of financial } \\
\text { services? }\end{array}$ & no \\
\hline & Loyalty to the local suppliers & no \\
\hline & Loyalty to salesperson & no \\
\hline
\end{tabular}




\section{Producer from Lucas do Rio Verde \\ Producer and Farm Characteristics}

This producer is a 55-year-old man, graduated in agronomy and the only responsible for planning and management activities, purchase of inputs and sale of production, being the primary decision maker of the farm. He lives in the city of Cuiabá, the capital of Mato Grosso, located 360 kilometers (223 miles) away from his farm. He has been farming for 26 years and agriculture represents $100 \%$ of his earnings. The production of his farm is based on soybean and rice, occupying an area of 1.200 hectares. The 2011 gross sales of his farm were between US\$2,000,000 and US $\$ 3,000,000$, which classify him as a large commercial producer, specifically in the State of Mato Grosso. This producer has high levels of productivity $(3.420 \mathrm{~kg} / \mathrm{ha}$ for soybeans and $6.000 \mathrm{~kg} / \mathrm{ha}$ for rice), high use of technology and he owns $100 \%$ of the land.

This condition creates a high level of investment in the farmlands. This producer hires specialized services of precision agriculture, purchases high technology equipment, utilizes pivot irrigation and storage systems. He also has a strategy for crop rotation focusing on the long term business sustainability and goals of productivity. For him, the productivity is linked to choice and rotation of crops, the level of technology adopted and the monitoring of diseases.

\section{Risk and Business Management}

This producer has no credit restrictions and he uses his own monetary resources to finance the production. He does not perform barter operations with local suppliers. He does forward contracts with trading companies, and he sells part of the production before harvest and the other part of it afterwards. This comfortable situation occurs due to the presence of storage systems (silobags) at the property, which allows him to choose the best time to market the production, hence increasing profitability. This structure reduces the risk of future price variations and allows for more profit to the producer. The lack of barter operations in this farm business provides great freedom of choice in the purchase of inputs and the opportunity to buy cheaper products. When buying equipment and machineries, he also uses government funding and private banks. This producer also takes part in an association and a cooperative. For him, the association is important because it creates benchmarking and management tools, which he uses for better decision making. The cooperative is important for production marketing and it also provides services of grain drying.

\section{Decision Making and Sources of Information}

This producer is exposed to advertisements from the Internet and magazines. He does not believe in such information and also verifies the veracity of this information through the local supplier technician, field days and product demonstrations, lectures, books and specialized magazines.

Also he believes that buying inputs is becoming more complex, because there are more options for purchasing inputs, more sales channels, products with similar functions and new products (micronutrients). This producer believes that there are differences between information from different local suppliers and he partially relies on such information, but for him, this situation does not affect his buying decision, since he believes that he is responsible for searching better information to make decisions. One factor that influences his buying decision is the infrastructure of the local supplier.

\section{Products and Suppliers Chosen}

This producer's main expected benefit when purchasing inputs is performance. Regarding equipment, both brand and quality of service are more important than price. For financial services acquired, the producer considers agility, price and amount as factors influencing his decision. These attributes are associated to a few brand companies, exerting a degree of influence on his buying behavior. One exception cited by him is that the quality of fertilizers and financial services is not related to a specific brand, which does not influence in buying behavior. For him, the only brand differences can be seen in seeds, chemicals and equipment. Fertilizers and financial services brands are considered as roughly the same. 
He is less loyal to the local supplier than the producer from Diamantino and Querência. He is free to promote transactions with other suppliers because he does not perform barter operations, i.e., he is not "stuck" in a package of products from a barter transaction. However, he is more loyal to the salesperson than the other producers, changing his local supplier when the salesperson moves to other company. In terms of prices, he believes that there are price differences between brands of seeds, chemicals and equipment. He is only loyal to the local suppliers of machines. Exhibit 2 shows the results of the interview with the producer from Lucas do Rio Verde, State of Mato Grosso, Brazil. 
Exhibit 2 - Consolidated results of the interview with the producer from Lucas do Rio Verde. State of Mato Grosso, Brazil.

\begin{tabular}{|c|c|c|}
\hline ucas do Rio Verde & Analytical column & $\begin{array}{c}\text { Results } \\
\end{array}$ \\
\hline \multirow{9}{*}{$\begin{array}{l}\text { roducer } \\
\text { haracteristics }\end{array}$} & Main activities on the farm & $\begin{array}{l}\text { Planning and management activities, } \\
\text { purchase of inputs and sales of production. }\end{array}$ \\
\hline & Level Decision Making & Only decision maker \\
\hline & Age & 55 years old \\
\hline & Gender & Male \\
\hline & Time in agriculture activity & 26 years \\
\hline & Education & Agronomic Engineer \\
\hline & Importance of agriculture in producer's income & $100 \%$ \\
\hline & Lives in the city? & Yes, Cuiabá \\
\hline & Distance property & $360 \mathrm{~km}$ \\
\hline \multirow{10}{*}{ arm Characteristics } & 2011 Gross Sales & between US $\$ 2,000,000$ and US $\$ 3,000,000$ \\
\hline & Production Area & 1.200 hectares \\
\hline & Land structure & $100 \%$ of owned lands. \\
\hline & Main Cultures & Soybean and rice \\
\hline & Productivity & $3.420 \mathrm{~kg} / \mathrm{ha}$ soybeans and $6.000 \mathrm{~kg} / \mathrm{ha}$ rice \\
\hline & Level of technology & High \\
\hline & Irrigation & Yes \\
\hline & Direct planting & Yes \\
\hline & Use of transgenic seeds & "Yes, $60 \%$ of production" \\
\hline & Crop Rotation and Crop Succession & "Yes, it is strategic for the business" \\
\hline \multirow{8}{*}{$\begin{array}{l}\text { isk and Business } \\
\text { Ianagement }\end{array}$} & Production Financing & Own funding \\
\hline & Equipment Financing & Government funding and private banks. \\
\hline & Credit Restrictions & No \\
\hline & Production Commercialization & $\begin{array}{l}\text { Forward contracts with trading companies, } \\
\text { Spot Market }\end{array}$ \\
\hline & Storage Systems & Yes \\
\hline & Member of an Association and/or Cooperative & Yes \\
\hline & What is the Influence of productivity on business management? & $\begin{array}{l}\text { The productivity is linked to choice and } \\
\text { rotation of crops, the level of technology } \\
\text { adopted and the monitoring of diseases }\end{array}$ \\
\hline & How may your farming operation change over the next five years? & $\begin{array}{l}\text { Will increase. The strategy to increase } \\
\text { productivity is precision agriculture and } \\
\text { crop rotation. }\end{array}$ \\
\hline \multirow{8}{*}{$\begin{array}{l}\text { ecision Making } \\
\text { id Sources of } \\
\text { formation }\end{array}$} & Sources of advertising / media & Internet and magazines \\
\hline & Do you trust the information provided by the media? & No \\
\hline & Sources of technical information & $\begin{array}{l}\text { local supplier technician, field days lectures, } \\
\text { specialized magazines, books }\end{array}$ \\
\hline & $\begin{array}{l}\text { Do you trust the information provided by sources of technical } \\
\text { information? }\end{array}$ & Yes \\
\hline & For you, is buying inputs becoming more complex? & Yes \\
\hline & $\begin{array}{l}\text { Are there differences between information from different local } \\
\text { suppliers? }\end{array}$ & Yes \\
\hline & Do you trust the information provided by your local supplier? & $\begin{array}{l}\text { Yes, but this situation does not affect his } \\
\text { buying decision }\end{array}$ \\
\hline & Regarding local suppliers, what influences your buying decision? & The infrastructure of the local supplier \\
\hline \multirow{11}{*}{$\begin{array}{l}\text { roducts and } \\
\text { uppliers }\end{array}$} & Inputs Expected benefits & Performance and quality \\
\hline & Equipment Expected benefits & Quality of service \\
\hline & Financial services Expected benefits & Agility and volume \\
\hline & Are there differences between brands of inputs? & yes \\
\hline & Are there differences between brands of equipment? & yes \\
\hline & Are there differences between brands of financial services? & no \\
\hline & Are there differences between prices of different brands of inputs? & yes \\
\hline & $\begin{array}{l}\text { Are there differences between prices of different brands of } \\
\text { equipment? }\end{array}$ & yes \\
\hline & $\begin{array}{l}\text { Are there differences between prices of different brands of financial } \\
\text { services? }\end{array}$ & no \\
\hline & Loyalty to the local suppliers & no \\
\hline & Loyalty to the salesperson & Yes \\
\hline
\end{tabular}




\section{Producer from Querência}

\section{Producer and Farm Characteristics}

This producer is a 55-year-old man, graduated in agronomy and the main responsible for planning and management activities, purchase of inputs and sale of production, being the primary decision maker of the farm. However, he shares his decisions with a partner who helps in farm operations. He lives in the city of Rondonópolis, located 700 kilometers (435 miles) away from his farm. He has been in farming for 12 years and agriculture represents $80 \%$ of his earnings. The distance between the place where he resides and the farm is the reason why his decisions are shared . In this case, inlocus decision-making is necessary in a higher level than the producer could offer.

The production of his farm is based on soybean and corn and covers an area of 1.750 hectares. The 2011 gross sales of his farm were between US\$ $2,000,000$ and US $\$ 3,000,000$, which classify him as a large commercial producer, specifically in the State of Mato Grosso. This producer presents medium levels of productivity $(3.330 \mathrm{~kg} / \mathrm{ha}$ for soybeans and $5.400 \mathrm{~kg} /$ ha for corn), medium use of technology and he owns $100 \%$ of the land.

This farm business portrays a peculiar situation: the choice of crops in the region of this producer is limited by logistical factors (transport and storage), which inhibit diversification to other crops. He only buys products for soybeans and corn.

\section{Risk and Business Management}

As well as the producer from Diamantino, this producer performs barter operations with trading companies to finance production, therefore exchanging part of the production for inputs before harvest. For him, this option is less profitable, but it is his only alternative to market the production, since there are no cooperatives in the region. Another reason for him to have opted for bartering is having financial restrictions. When buying equipment and machines, he uses government funding and private banks.

Also like the producer from Diamantino, he recognized that the barter operation makes the producer more loyal to the local supplier reducing then his information search for inputs, hence negatively affecting his profitability and investment level. It is noteworthy that the barter operation is held by this producer due to his credit restrictions from banks and other financial agents being one of the few sources of production financing. This producer also takes part in an association. For him, the association is important because it assists him in his risk management, it gives him support on technical issues, and it provides orientation in rural credit and grain classification. Although he does not participate in a cooperative, the producer recognizes its importance in organizing buying pools, marketing large volumes and providing support with administrative tools.

\section{Decision Making and Sources of Information}

This producer is exposed to advertisements from television, newspaper, Internet and email. He partially believes in such information and he also searches technical information via local supplier, specialized consulting, association, product experimentation and field days, research and technical agencies and other producers. Unlike the other two producers, he does not believe that buying inputs is becoming more complex, because there are more research information possibilities, greater exchange of experience among producers and evolution of the products available in the market.

This producer believes that there are differences between information from different local suppliers and he partially relies on such information, besides believing that this difference influences his buying behavior. Factors that influence his buying decision are infrastructure, product line extension, commercial approach, technical assistance and relevant information.

\section{Products and Suppliers Chosen}

This producer's main expected benefit when buying inputs is price. Regarding equipment, price is more important than performance and convenience. For financial services acquired, the producer considers agility, price and amount as factors influencing his decision. 
These attributes are associated to a few brand companies, exerting a degree of influence on his buying behavior. Similarly to the other two producers, one exception cited by him is that the quality of fertilizers and financial services is not related to a specific brand, which does not influence his buying behavior. For him, the only brand differences can be identified in seeds, chemicals and equipment. Fertilizers and financial services brands are considered as relatively the same.

In terms of prices, he believes that there are price differences between brands of seeds, chemicals and equipment. He is more loyal to the local supplier than the producers from Diamantino and Lucas do Rio Verde, buying only from one local supplier.

Exhibit 3 shows the results of the interview with the producer from Querência, State of Mato Grosso, Brazil. 
Exhibit 3 - Consolidated results of the interview with the producer from Querência. State of Mato Grosso, Brazil.

\begin{tabular}{|c|c|c|}
\hline Querência & Analytical column & Results \\
\hline & Main activities on the farm & $\begin{array}{l}\text { Planning and management activities, purchase of } \\
\text { inputs and sales of production. }\end{array}$ \\
\hline & Level Decision Making & Main decider, sharing the decision with a manager \\
\hline & Age & 55 years \\
\hline Producer & Gender & Male \\
\hline \multirow[t]{9}{*}{ Characteristics } & Time in agriculture activity & 12 years \\
\hline & Education & Agronomic Engineer \\
\hline & Importance of agriculture in producer income & $80 \%$ \\
\hline & Lives in the city? & Yes, Rondonópolis \\
\hline & Distance property & $700 \mathrm{~km}$ (435 miles) \\
\hline & 2011 Gross Sales & between US\$2,000,000 and US\$3,000,000 \\
\hline & Production Area & 1.750 hectares \\
\hline & Land structure & $100 \%$ of proper lands \\
\hline & Main Cultures & soybeans and corn \\
\hline Farm & Productivity & $3.330 \mathrm{~kg} / \mathrm{ha}$ soybeans and $5.400 \mathrm{~kg} / \mathrm{ha}$ corn \\
\hline \multirow{10}{*}{ Characteristics } & Level of technology & Medium \\
\hline & Irrigation & No \\
\hline & Direct planting & Yes \\
\hline & Use of transgenic seeds & $90 \%$ for corn; $100 \%$ for soybeans \\
\hline & Crop Rotation and Crop Succession & Yes \\
\hline & Production Financing & Barter Operations \\
\hline & Equipment Financing & Government funding and private banks. \\
\hline & Credit Restrictions & Yes \\
\hline & Production Commercialization & Via Trading Company \\
\hline & Storage Systems & No \\
\hline \multirow{7}{*}{$\begin{array}{l}\text { Risk and } \\
\text { Business } \\
\text { Management }\end{array}$} & Member of an Association and/or Cooperative & Yes \\
\hline & & Is directly linked to the ability of investment \\
\hline & What is the Influence of productivity on business management? & $\begin{array}{l}\text { business. Due to weather issues, the producer lost } \\
10 \% \text { of productivity compared to previous crops } \\
\text { and now has operational problems. }\end{array}$ \\
\hline & $\begin{array}{l}\text { How may your farming operation change over the next five } \\
\text { years? }\end{array}$ & $\begin{array}{l}\text { Will increase. He bought better equipment and is } \\
\text { organizing to return to the default of } 60 \text { sacks of } \\
\text { soybeans. The difficulty is accessing credit. }\end{array}$ \\
\hline & Sources of advertising / media & Television, newspaper, Internet and email \\
\hline & Do you trust the information provided by the media? & Partially \\
\hline & Sources of technical information & $\begin{array}{l}\text { Technical information via local supplier, } \\
\text { specialized consulting, association field days, } \\
\text { technical agencies and other producers. }\end{array}$ \\
\hline \multirow{11}{*}{$\begin{array}{l}\text { Decision } \\
\text { Making and } \\
\text { Sources of } \\
\text { Information }\end{array}$} & $\begin{array}{l}\text { Do you trust the information provided by sources of technical } \\
\text { information? }\end{array}$ & Yes \\
\hline & For you, is buying inputs becoming more complex? & No \\
\hline & $\begin{array}{l}\text { Are there differences between information from different local } \\
\text { suppliers? }\end{array}$ & Yes \\
\hline & Do you trust the information provided by your local supplier? & Yes \\
\hline & $\begin{array}{l}\text { Regarding local suppliers, what influences your buying } \\
\text { decision? }\end{array}$ & $\begin{array}{l}\text { infrastructure, product line, commercial approach, } \\
\text { technical assistance and relevant information }\end{array}$ \\
\hline & Inputs Expected benefits & Price \\
\hline & Equipment Expected benefits & Price \\
\hline & Financial services Expected benefits & Agility, price and volume \\
\hline & Are there differences between brands of inputs? & Yes \\
\hline & Are there differences between brands of equipment? & Yes \\
\hline & Are there differences between brands of financial services? & No \\
\hline \multirow[t]{5}{*}{$\begin{array}{l}\text { Products and } \\
\text { Suppliers }\end{array}$} & $\begin{array}{l}\text { Are there differences between prices of different brands of } \\
\text { inputs? }\end{array}$ & Yes \\
\hline & $\begin{array}{l}\text { Are there differences between prices of different brands of } \\
\text { equipment? }\end{array}$ & Yes \\
\hline & $\begin{array}{l}\text { Are there differences between prices of different brands of } \\
\text { financial services? }\end{array}$ & No \\
\hline & Loyalty to the local suppliers & Yes \\
\hline & Loyalty to the salesperson & No \\
\hline
\end{tabular}




\section{Joint Analysis And Conclusions}

In this paper we have developed familiarity with the nature of the farming business model and its influence on the buying behavior of grain producers in the State of Mato Grosso-Brazil. We have outlined the studied producers and their farms, as well as the business itself and risk management practices, the decision making process and the information sourcing, and by doing so, we have established the relation of such topics to the process of buying inputs, capital goods and financial services.

\section{Main findings}

In this study we have identified the determinants of buying behavior of three Large Commercial Producers of grains in the Estate of Mato Grosso, Brazil. Our findings relate to the Producer's and Farm Characteristics, Risk and Business Management, Decision Making and Information Sources, Products, Suppliers and their impact on the buying behavior of such farmers. We have described these features below.

Regarding the Characteristics of the Producer, the main determinants of buying behavior of the producers considered in the study are the activities they perform in the business, the level of engagement in the decision making process, education, having a specific office to purchase the goods, age and time in activity.

Regarding the Characteristics of the Farm, the main determinants of buying behavior of these producers are the size of the farming operation, the variety of crops, productivity and profitability, land leasing, crop rotation and crop succession. It is important to highlight that land leasing negatively influences the long-term investments in agricultural business, especially when purchasing fertilizers and promoting crop succession.

Regarding the Risk and Business Management, the main determinants of buying behavior of the interviewed farmers are risk aversion, sources for financing the costs of production and machinery, forms of commercialization of the production, level of complexity of the purchase, professionalization, participation in cooperatives and associations and credit restrictions.

Regarding the Decision Making Process and Sources of Information, the main determinants of buying behavior of these producers are sources of information (media/advertising and technical), the quality of information and external influence of the local supplier on the buying center.

Regarding the Products, their main determinants of buying behavior are the expected benefit, involvement in the purchase and brand influence.

Regarding the Local Suppliers, the main determinants of buying behavior of these producers are loyalty to the local supplier and to the salesperson, the quality of information of the local supplier and the salesperson's attributes.

Although we must not generalize these determinants to other producers and farm businesses, we have built a framework consolidating the determinants for buying behavior based on all of our findings, in order to simplify the analysis, as shown on Exhibit 4. 
Exhibit 4 - Consolidated framework with determinants of the buying behavior of the studied producers.

\begin{tabular}{|c|c|c|c|c|}
\hline $\begin{array}{l}\text { Producer } \\
\text { Characteristics }\end{array}$ & $\begin{array}{l}\text { Farm } \\
\text { Characteristics }\end{array}$ & $\begin{array}{l}\text { Risk and Business } \\
\text { Management }\end{array}$ & $\begin{array}{l}\text { Decision Making and } \\
\text { Sources of Information }\end{array}$ & Products and Suppliers \\
\hline $\begin{array}{l}\text { Activities undertaken } \\
\text { by the producer }\end{array}$ & Land Leasing & Risk aversion & Sources of information & Expected benefit \\
\hline Buying office & culture produced & $\begin{array}{l}\text { Sources of funding for } \\
\text { purchase of machinery }\end{array}$ & $\begin{array}{l}\text { Quality of information of } \\
\text { the local supplier }\end{array}$ & $\begin{array}{l}\text { Involvement in the } \\
\text { purchase }\end{array}$ \\
\hline Level of Education & $\begin{array}{l}\text { Productivity and } \\
\text { profitability }\end{array}$ & $\begin{array}{l}\text { Sources of funding for } \\
\text { production costing }\end{array}$ & $\begin{array}{l}\text { External influence in } \\
\text { buying center }\end{array}$ & Brand influence \\
\hline Age & Crop rotation & $\begin{array}{l}\text { Form of market } \\
\text { production }\end{array}$ & Other producers & $\begin{array}{l}\text { Loyalty to the local } \\
\text { supplier and salesperson, }\end{array}$ \\
\hline $\begin{array}{l}\text { Level of } \\
\text { professionalization }\end{array}$ & Succession of crops & $\begin{array}{l}\text { Level of complexity of } \\
\text { the purchase }\end{array}$ & & $\begin{array}{l}\text { quality of information of } \\
\text { the local supplier }\end{array}$ \\
\hline $\begin{array}{l}\text { Level of involvement } \\
\text { in decision }\end{array}$ & Size of the activity & $\begin{array}{l}\text { Level of } \\
\text { professionalization }\end{array}$ & & Salesperson attributes \\
\hline Time in activity & Precision Agriculture & $\begin{array}{l}\text { Presence in cooperatives } \\
\text { and associations }\end{array}$ & & \\
\hline $\begin{array}{l}\text { Distance from the } \\
\text { residence to the } \\
\text { property }\end{array}$ & $\begin{array}{l}\text { Age of machinery and } \\
\text { equipment }\end{array}$ & Credit constraints & & \\
\hline $\begin{array}{l}\text { Importance of } \\
\text { agricultural activity in } \\
\text { producer's income }\end{array}$ & Direct Planting & $\begin{array}{l}\text { Future changes in } \\
\text { production }\end{array}$ & & \\
\hline $\begin{array}{l}\text { Influence of other } \\
\text { producers }\end{array}$ & Use of Transgenic & $\begin{array}{l}\text { Hiring activities of third } \\
\text { parties }\end{array}$ & & \\
\hline Family succession & Use of irrigation & $\begin{array}{l}\text { Level of contact with the } \\
\text { technical bodies of the } \\
\text { sector } \\
\text { Warehouse presence on } \\
\text { the farm } \\
\text { Use of services of local } \\
\text { suppliers } \\
\text { logistics and storage }\end{array}$ & & \\
\hline
\end{tabular}

In this paper, we have identified and analyzed the determinants of the buying behavior of three producers of grains in the State of Mato Grosso and the relation of such behavior to the buying process of inputs, capital goods and financial services. The results may help suppliers to better market their products and services to producers and, in addition, they may also encourage future quantitative researches. We suggest another future quantitative research that consists of statistically testing the impacts of the determinants revealed by this study on the buying behavior of these farmers. What are the correlations among the determinants? Which one is the strongest determinant? Are these factors really affecting the buying behavior of all Large Commercial Producers of grains in the State of Mato Grosso, Brazil? Regarding other types of farm business, like sugar-cane, orange or livestock production, are the determinants similar to the ones we have found? Where is the difference?

The most successful companies are those that proactively adapt their strategy to the customer's needs. Understanding the customer's needs, values, buying behavior and decision making process is fundamental to any marketing strategy. This process becomes the basis for the development of products and services, design, pricing, distribution and effective media. In this sense, the research about the determinants of buying behavior of farmers can assist input supply companies in identifying, targeting and delivering a unique value proposition to these producers, therefore generating value for the input supplier and for rural production segments. 


\section{REFERENCES}

ALEXANDER, C. E., BOEHLJE, M., DOWNEY, S., GRAY, A. W, GUNDERSON, M. \& ROUCAN-KANE,M. Serving Producers in Volatile Times. Themes from the 2008 Large Commercial Producers. Center for Food and Agricultural Business, Department of Agricultural Economics, Purdue University, 2008.

BOEHLJE, M., DOEHRING, T., SONKA, S. Farmers of the Future: Market Segmentation a Buying Behavior. International Food and Agribusiness Management Review, v.8, n.3, p. 52-68, 2005.

BORCHERS, B., ROUCAN-KANE, M., ALEXANDER, C., BOEHLJE, W., DOWNEY, S., GRAY, A. W. How Large Commercial Producers Choose Input Suppliers: Expendable Products from Seed to Animal Health. International Food and Agribusiness Management Review. v. 15, Issue 2, 2012.

BURGERT, G. W. Agricultural Large Commercial Producers in Argentina and the United States of America: a Comparative Study. Master of Science Thesis. Center for Food and Agricultural Business, Department of Agricultural Economics, Purdue University, 2011.

FEENEY, R., BERARDI, V., BERTOSSI, O., STEIGER, C., PIAZZARDI. "The Needs of Argentine Farmers", Center for Food and Agribusiness, Austral University, Argentina, 2009.

FUNK, T. F., TARTE, F. C. The Farmer Decision Process in Purchasing Broiler Feed. American Journal of Agricultural Economics, Oxford, v. 60, n. 4, nov. , 1978, p. 678. Oxford University Press on behalf of the Agricultural \& Applied Economics Association, 1978.
GLOY, B. A., AKRIDGE, J. T. Segmenting the Commercial Producer Marketplace for Agricultural Inputs. International Food and Agribusiness Management Review. v. 2, 1 45-163. 1999.

HABERLI JR, C. Segmentação de Marcas de Fertilizantes por Estilo de Vida do Produtor Rural. Master of Science Thesis. Universidade Metodista de Piracicaba. UNIMEP. Piracicaba, SP, 2006.

KOOL, M. Buying Behavior of Farmers. Doctor of Philosophy Thesis. Wageningen Pers. Wageningen, The Netherlands, 1994.

MERRIAM, S. B. Case study research in education: a qualitative approach. 1sted. San Francisco: Jossey-Bass, 1988.

ROSSI, R. M., NEVES, M. F., TORNAVOI, D. "Buying Process Characteristics of Citrus Growers from São Paulo State, Brazil, Related to Foliar Fertilizers. CONGRESS OF THE RURAL ECONOMICS AND ADMINISTRATION., 41. SOBER, Juiz de Fora, 2003.

SCARE, R. F., AFONSO, R. A., LIMA JR, J. C., TORRES JR, A. M. A Buying Behavior and Segment Analysis of Cattle Breeders in Brazil. International Food and Agribusiness Annual World Symposium IFAMA, Frankfurt, 2011.

SCARE, R. F., ANTOLINI, L. S., MIRANDOLA, F. P. Análise do Processo Decisório de Compra de Inseminação Artificial por Pecuaristas de Gado de Corte. CONGRESS OF THE BRAZILIAN SOCIETY OF SOCIOLOGY., 50. Rural Economics and Administration (SOBER), Vitória, 2012.

SCHNEPF, R.D.; DOHLMAN, E.; BOLLING, C. Agriculture in Brazil and Argentina: developments and prospects for major field crops. 
Washington: ERS/USDA, 2001.

SILVA, A. P. S., SCARE, R. F., CASANOVA, A. C. P. Análise do Processo de Compra do Consumidor Agropecuário. 2008. CONGRESS OF THE BRAZILIAN SOCIETY OF SOCIOLOGY.,47. RuralEconomics and Administration SOBER, Rio Branco, 2008.
STRATEGIC MANAGEMENT ADVISORY BOARD OF THE MINISTRY OF AGRICULTUREAND LIVESTOCK AND SUPPLY - Mapa 2010 Brazilian Agribusiness Projections Report2010/2011 - 2020/2021.

YIN R.K. Estudo de caso: planejamento e métodos. Porto Alegre: Bookman, 2005. 212 p. 